ISSN 0258-7122

Bangladesh J. Agril. Res. 38(4): 719-732, December 2013

\title{
GROWTH AND YIELD OF WHEAT (Triticum aestivum) UNDER DEFICIT IRRIGATION
}

\author{
P. K. SARKAR ${ }^{1}$, M. S. U. TALUKDER ${ }^{2}$, S. K. BISWAS ${ }^{3}$ \\ AND A. KHATUN ${ }^{4}$
}

\begin{abstract}
Timing and the extent of water deficit were studied in a field experiment on wheat (cv. Shatabdi) for three consecutive years from 2003-04 through 2005-06 at Jamalpur area. The effects of number and timing of irrigation application on yields were investigated under variable soil moisture condition in the root zone of different treatments. Eight deficit irrigations, including one no stress and one rainfed treatments were selected to subject the crop to various degrees of soil water deficit at different stages of crop growth. Measured amount of irrigation water was applied as per schedule prescribed for a particular treatment. Grain yield (GY), biomass, harvest index (HI), and water productivity (WP) were reasonably affected by deficit irrigation. Other yield contributing parameters like 1000-grain weight, grains/spike and spike, length were also affected by different levels of deficit irrigation. During grain formation stage, water deficit did not affect the grain yield but saved water significantly. Such water deficit treatments also shortened the grain maturation period. Differences in grain and straw yield among the stressed and no stress treatments are comparatively small, and statistically insignificant in some cases. The highest water productivity (2.02 $\mathrm{kg} / \mathrm{m}^{3}$ ) was observed in treatment which was irrigated only once at crown root initiation stage $\left(\mathrm{T}_{2}\right)$ although the yield was comparatively low. The CRI (crown root initiation) stage was found the most sensitive to water stress. Water stress at vegetative stage also reduced the yield considerably.
\end{abstract}

Keywords: Deficit irrigation, water productivity, leaf area index, dry matter, consumptive use.

\section{Introduction}

Water stress affects crop growth and productivity in many ways. Most of the responses have a negative effect on production but crops have different and often complex mechanisms to react to shortages of water. Several crops and genotypes have developed different degrees of drought tolerance, drought resistance or compensatory growth to deal with periods of stress. The highest crop productivity is achieved for high yielding varieties with optimal water supply and high soil fertility levels, but under stressed conditions, crops will adapt to water stress and can produce well with less water.

${ }^{1}$ Principal Scientific Officer \& Head, ${ }^{3}$ Senior Scientific Officer, ${ }^{4}$ Principal Scientific Officer, IWM Division, Bangladesh Agricultural Research Institute (BARI), Gazipur; ${ }^{2}$ Professor, Dept. of IWM, Bangladesh Agricultural University (BAU), Mymensingh, Bangladesh. 
Deficit irrigation practices differ from traditional water supply practices. Farmer needs to know the level of transpiration deficiency allowable without significant reduction in crop yields.

The main objective of deficit irrigation is to increase the water use efficiency (WUE) of a crop by eliminating irrigation that has a little impact on yield. The resulting yield reduction may be small compared to the benefits gained through diverting the saved water to irrigate other crops for which water would normally be insufficient under traditional irrigation practices. The plant water deficits that develop at any particular situation is the result of a complex combination of soil, plant, and atmospheric factors, all of which interact to control the rate of water absorption and water loss (Kramer, 1959 and Vaadia et al., 1961).

Zhang et al. (2004) reported that deficit irrigation is a form of water conserving irrigation scheduling. The basic information needed to adopt this technique is to know the response of water deficit for various growth stages of the crop. Controlled soil water deficit inhibits the stem elongation, stimulates root system development and therefore, results in a substantially enhanced rootto-shoot ratio. The patterns of soil moisture are similar in the regulated deficit treatments, and the soil moisture contents are greatly decreased by regulated deficit irrigation during wheat growing seasons.

To cope with droughts and water scarcity in semi-arid to sub-humid climates, the irrigators require the development of preparedness measures. For irrigated agriculture, these include the identification of irrigation scheduling strategies that minimize the water demand with acceptable impacts on yields. Those strategies may be produced by simulation and focus of different levels of water demand, from average to drought conditions (Rodrigues et al., 2001).

The use of water for agricultural production in water scarcity regions requires innovative and sustainable research and an appropriate transfer of technologies. The sustainability use of water- resource conservation, environmental friendliness, appropriateness of technologies, economic viability, and social acceptance of development issues- is a priority for agriculture in water scarce regions. Innovations are, therefore, required mainly to irrigation management and practice since the agriculture sector is far ahead in demand for water in those regions (Pereira et al., 2002).

Before implementing a deficit irritation programme, it is necessary to know crop yield responses to water stress, either during defined growth stages or throughout the whole season (Kirda and Kanber, 1999). Ali et al. (2008) reported that Deficit irrigation is very much effective to improve water productivity. The highest water productivity and productivity of irrigation water were obtained in alternate deficit treatment where deficits were imposed at maximum tillering (jointing to shooting) and flowering to soft dough stages of growth period 
followed by single irrigation at crown root initiation (CRI) stage. Under both land and water limiting conditions, alternate deficit strategy showed maximum net financial return.

In order to ensure successful deficit irrigation, it is necessary to know the water retention capacity of the soil. In sandy soils, plants may undergo water stress quickly under deficit irrigation, whereas plants in deep soils of fine texture may have ample time to adjust to low soil water potential, and may remain unaffected by low soil water content. Therefore, success with deficit irrigation is more probable in fine textured soils.

In the past, limitations in available water supplies were not taken into considerations while estimating crop water requirements. Also the design of irrigation schemes did not address situations of moisture availability as the major constraint to crop yields. However, in arid and semi-arid regions, increasing demands for water are necessitating major changes in irrigation management and scheduling in order to increase the efficiency of use of water allocated to agriculture.

In the context of improving water productivity, there is a growing interest in deficit irrigation, an irrigation practice whereby water supply is reduced below maximum levels and mild stress is allowed with minimal effects on yield. Under conditions of scarce water supply and drought, deficit irrigation can lead to greater economic gains than maximizing yields per unit of water for a given crop. Farmers are more inclined to use water more efficiently. However, this approach requires precise knowledge of crop response to water as drought tolerance varies considerably by species, cultivar and stage of growth.

With the above considerations, it appears that there is ample scope of practicing deficit irrigation management for wheat cultivation. It is also important to study its effectiveness taking the dynamics of the climate-crop-water interactions into account. Besides, the results of the researchers in other countries may not be directly applicable to Bangladesh condition. Hence, a study on deficit irrigation in local condition and climate may be helpful to improve irrigation management of wheat. The general objective of the study was to predict the impact of deficit irrigation on wheat cultivation. The specific objectives were as follows:

i) to investigate the impact of imposing water stress on growth, development and yield of wheat, and

ii) to identify the growth stages of wheat more sensitive to soil water deficit. 


\section{Materials and Method}

The study was conducted at the research farm of Regional Agricultural Research Station (RARS), Jamalpur during 2003-2004 to 2005-2006 years. The area lies on $24^{\circ} 56^{\prime} 44.6^{\prime \prime}$ latitude and $89^{\circ} 55^{\prime} 86.9^{\prime \prime}$ longitudes. The average elevation of the tract from mean sea level is $16.5 \mathrm{~m}$. The climate is of temperate semi-arid monsoon type. The maximum mean air temperature ranges from $24^{\circ} \mathrm{C}$ to $36^{\circ} \mathrm{C}$ and the minimum from $10^{\circ} \mathrm{C}$ to $25^{\circ} \mathrm{C}$, respectively. Mean annual precipitation is $1360 \mathrm{~mm}$ of which about 75 \% occurs from June to September (Manalo, 1976). The soil series of the study area has been identified to fall under agro-ecological zone 9 (Old Brahmaputra Flood Plain). The soil of the experimental field was mainly silty loam type having an average apparent specific gravity of 1.52 . Average field capacity and permanent wilting point were $30 \%$ and $12 \%$, respectively on weight basis. Wheat (cv. Shatabdi) was used as the test crop for the study. The experiment was laid out in RCBD design and replicated thrice. The selected treatment set-up was as follows.

$\mathrm{T}_{1}=$ Rainfed (No irrigation)

$\mathrm{T}_{2}=$ One irrigation at crown root initiation (CRI) stage

$\mathrm{T}_{3}=$ Two irrigations: CRI and flowering stages

$\mathrm{T}_{4}=$ Four irrigations: CRI, vegetative, heading and flowering stages

$\mathrm{T}_{5}=$ Five irrigations: CRI, vegetative, heading, flowering and grain formation stages

$\mathrm{T}_{6}=$ Four irrigations: vegetative, heading, flowering and grain formation stages

$\mathrm{T}_{7}=$ Three irrigations: CRI, vegetative and heading stages

$\mathrm{T}_{8}=$ Three irrigations: vegetative, heading and flowering stages

$\mathrm{T}_{9}=$ Two irrigations: $\mathrm{CRI}$ and vegetative stages

$\mathrm{T}_{10}=$ Two irrigations: heading and flowering stages

Irrigation was applied as per treatment set-up. Data on time and amount of irrigation were collected during the whole cropping season. Important crop growth and development parameters like plant height (PH), leaf area index (LAI) and dry matter (DM) accumulation were collected at different growth stages. Data on different agronomic parameters were also collected and duly analyzed statistically.

Seeds were sown on $25^{\text {th }}, 24^{\text {th }}$, and $21^{\text {st }}$ of November during the three study years, respectively and the crop was harvested in mid-March of the following years. Seed rate was $120 \mathrm{~kg} / \mathrm{ha}$. Chemical fertilizers were applied as basal at the rate of $\mathrm{N}_{150} \mathrm{P}_{100} \mathrm{~K}_{150} \mathrm{~kg} / \mathrm{ha}$ as suggested in the Fertilizer Recommendation Guide (2005) for the study area. Plots were hand-harvested individually and a thresher was used to separate the grains. 
Soil water content for the individual plot was monitored gravimetrically before and after each irrigation. Soil sampling was done at depths of 15, 30, 45, and $60 \mathrm{~cm}$. Consumptive use (CU) of the crop was calculated using the Equation 1 as follows.

$\mathrm{CU}=\Delta \mathrm{S}+\mathrm{P}+\mathrm{I}+\mathrm{D}+\mathrm{R}$

where: $\mathrm{CU}=$ Consumptive use (CU) of the crop, $\mathrm{mm}$

$\Delta \mathrm{S}=$ the change in soil water storage, $\mathrm{mm}$

$\mathrm{P}=$ precipitation (rainfall), $\mathrm{mm}$

I = irrigation applied, $\mathrm{mm}$

$\mathrm{D}=$ drainage from the bottom of root zone, $\mathrm{mm}$

$\mathrm{R}=$ run off, $\mathrm{mm}$

As rainfall intensity was very low during cropping season, no runoff occurred and drainage from the root zone was considered negligible since measured amount of water was applied. Thus, CU was the sum of rainfall, irrigation and the change in soil water storage.

\section{Results and Discussion}

Rainfall distribution during the cropping periods (November to March) of the study years is presented in Table 1. Except 2004-05 season, the other two seasons were very dry. Only $2 \mathrm{~mm}$ rainfall occurred in 2005-06 cropping season and 14 $\mathrm{mm}$ in 2003-2004. As a result, rainfall contributions to soil water in the root zone during those two years were negligible.

Table 1. Rainfall distribution during the three study years.

\begin{tabular}{c|c|c|c|c|c|c}
\hline Months & $\begin{array}{c}\text { November } \\
(\mathrm{mm})\end{array}$ & $\begin{array}{c}\text { December } \\
(\mathrm{mm})\end{array}$ & $\begin{array}{c}\text { January } \\
(\mathrm{mm})\end{array}$ & $\begin{array}{c}\text { February } \\
(\mathrm{mm})\end{array}$ & $\begin{array}{c}\text { March } \\
(\mathrm{mm})\end{array}$ & $\begin{array}{c}\text { Total } \\
\text { rainfall } \\
(\mathrm{mm})\end{array}$ \\
\hline $2003-2004$ & 0 & 14 & 0 & 0 & 0 & 14 \\
$2004-2005$ & 0 & 0 & 3 & 23 & 40 & 66 \\
$2005-2006$ & 0 & 0 & 0 & 0 & 2 & 2 \\
\hline
\end{tabular}

\section{Effect of water deficit on growth parameters}

\section{Plant height}

Effects of water deficit of different levels at different stages of the crop are presented in Table 2. Plant height for all treatments was almost similar up to the crown root initiation (CRI) stage, as no supplemental irrigation was applied before that stage to any treatment. However, a marked decline was observed when moisture stress was imposed at CRI stage to treatments $T_{1}, T_{6}, T_{8}$, and $T_{10}$. 
No appreciable difference in plant height was observed between $T_{4}$ and $T_{5}$ indicating no reasonable effect of irrigation on plant height at grain formation (GF) stage.

Table 2. Plant height as affected by deficit irrigation during the study years.

\begin{tabular}{|c|c|c|c|c|c|c|}
\hline \multirow[b]{2}{*}{ Treatment } & \multirow{2}{*}{$\begin{array}{l}\text { No of } \\
\text { irrigations }\end{array}$} & \multicolumn{5}{|c|}{ Plant height (cm) } \\
\hline & & CRI & Vegetative & $\begin{array}{c}\text { Booting- } \\
\text { head. }\end{array}$ & Anthesis & GF \\
\hline $\mathrm{T}_{1}$ & 0 & 26.25 & 43.75de & 75.10cd & 85.15cd & $87.60 \mathrm{c}$ \\
\hline $\mathrm{T}_{2}$ & 1 & 25.65 & 45.80cd & 76.95bcd & 92.55ab & 93.17abc \\
\hline $\mathrm{T}_{3}$ & 2 & 25.55 & 45.85de & $79.00 \mathrm{bc}$ & $90.87 a b$ & $94.20 \mathrm{ab}$ \\
\hline $\mathrm{T}_{4}$ & 4 & 27.70 & 48.90ab & 80.05ab & $95.30 \mathrm{a}$ & 97.93ab \\
\hline $\mathrm{T}_{5}$ & 5 & 26.00 & $49.95 a$ & $84.75 a$ & 94.23ab & 98.56a \\
\hline $\mathrm{T}_{6}$ & 4 & 25.15 & $40.65 f$ & $69.45 \mathrm{e}$ & 89.15bcd & $96.78 \mathrm{ab}$ \\
\hline $\mathrm{T}_{7}$ & 3 & 25.10 & $45.65 \mathrm{~cd}$ & 76.90bcd & 89.95abc & $94.20 \mathrm{ab}$ \\
\hline $\mathrm{T}_{8}$ & 3 & 25.05 & 44.78de & 72.75de & 93.45ab & $97.05 \mathrm{ab}$ \\
\hline $\mathrm{T}_{9}$ & 2 & 25.65 & $47.30 \mathrm{bc}$ & $79.00 \mathrm{bc}$ & $91.80 \mathrm{ab}$ & $96.00 \mathrm{ab}$ \\
\hline $\mathrm{T}_{10}$ & 2 & 26.25 & 42.95ef & 74.30ce & $83.65 d$ & $92.10 \mathrm{bc}$ \\
\hline CV (\%)) & - & 11.94 & 3.19 & 4.13 & 3.56 & 3.76 \\
\hline LSD (5\% & - & NS & 2.481 & 5.448 & 5.535 & 6.115 \\
\hline
\end{tabular}

\section{Leaf area index}

The leaf area index (LAI) of no stress treatment $\left(\mathrm{T}_{5}\right)$ increased slowly in response to tillering and development of new leaves from seedling growth to the CRI stage (Table 3). Thereafter, it increased rapidly up to the heading stage due to the increase in number of stems, leaves per stem and area per leaf. It again decreased rapidly from heading, because of the leaf growth had almost stopped and that the senescence of older leaves had already started due to translocation of dry matter to the spikes.

Compared with no stress plants, moisture stress decreased the leaf area index in all treatments by reducing leaves per stem, area per leaf, number of stems per plant and by increasing number of wilted leaves except for plants stressed at the grain formation stage (treatment $\mathrm{T}_{4}$ ). Obviously, the leaf area index was mostly affected when stress was imposed throughout the cropping period (treatment $T_{1}$ ). Since stress was imposed in treatment $T_{6}, T_{8}$, and $T_{10}$ at CRI stage, the leaf area growth was stunted from that stage. 
Table 3. Leaf area index as affected by deficit irrigation during the study years.

\begin{tabular}{c|l|l|l|l}
\hline \multirow{2}{*}{ Treatment } & \multicolumn{5}{c}{ Leaf area index } \\
\cline { 2 - 5 } & \multicolumn{1}{|c}{ CRI } & \multicolumn{1}{c}{ Vegetative } & \multicolumn{1}{c}{ Booting-head. } & Anthesis \\
\hline $\mathrm{T}_{1}$ & $0.89 \mathrm{bcd}$ & $1.95 \mathrm{de}$ & $2.00 \mathrm{e}$ & $1.26 \mathrm{f}$ \\
$\mathrm{T}_{2}$ & $0.96 \mathrm{bc}$ & $2.26 \mathrm{bcd}$ & $2.68 \mathrm{bcd}$ & $1.80 \mathrm{de}$ \\
$\mathrm{T}_{3}$ & $0.87 \mathrm{~cd}$ & $2.19 \mathrm{~cd}$ & $2.77 \mathrm{bc}$ & $2.22 \mathrm{c}$ \\
$\mathrm{T}_{4}$ & $1.14 \mathrm{a}$ & $2.32 \mathrm{abc}$ & $3.48 \mathrm{a}$ & $2.86 \mathrm{~b}$ \\
$\mathrm{~T}_{5}$ & $0.83 \mathrm{~cd}$ & $2.62 \mathrm{a}$ & $2.93 \mathrm{~b}$ & $3.16 \mathrm{a}$ \\
$\mathrm{T}_{6}$ & $0.82 \mathrm{~d}$ & $1.86 \mathrm{e}$ & $1.97 \mathrm{e}$ & $1.88 \mathrm{de}$ \\
$\mathrm{T}_{7}$ & $1.00 \mathrm{~b}$ & $2.23 \mathrm{~cd}$ & $2.52 \mathrm{~cd}$ & $1.84 \mathrm{de}$ \\
$\mathrm{T}_{8}$ & $0.91 \mathrm{bcd}$ & $1.79 \mathrm{e}$ & $2.48 \mathrm{~cd}$ & $1.99 \mathrm{~cd}$ \\
$\mathrm{~T}_{9}$ & $0.95 \mathrm{bcd}$ & $2.58 \mathrm{ab}$ & $2.91 \mathrm{~b}$ & $2.18 \mathrm{c}$ \\
$\mathrm{T}_{10}$ & $0.87 \mathrm{~cd}$ & $1.81 \mathrm{e}$ & $2.00 \mathrm{e}$ & $1.68 \mathrm{e}$ \\
\hline $\mathrm{CV}(\%)$ & 8.07 & 8.73 & 7.09 & 7.94 \\
LSD (5\%) & 0.133 & & 0.316 & 0.282 \\
\hline
\end{tabular}

The results indicate that moisture stress at any stage of crop growth and development decreased the leaf area index. However, after termination of stress, crop showed a trend to recover the growth depending upon the growth stage at which moisture stress was imposed. The results clearly showed that moisture stress occurring at CRI stage decreased the overall LAI considerable (e.g., $\mathrm{T}_{6}$ ) due to reduction in number of stems (tillers) and number of leaves per stem during vegetative growth stages, although no stress was imposed throughout the rest of the cropping period.

\section{Dry matter (DM) accumulation}

Table 4 reveals the trend of average DM accumulation of different treatments. Total dry matter accumulation decreased considerably in almost all moisture stressed treatments (except stress at grain formation stage) compared to no stress treatment $\left(T_{5}\right)$. The effect was most severe when stress was imposed from CRI to vegetative stage (treatments $\mathrm{T}_{6}$ and $\mathrm{T}_{10}$ ) mainly by affecting the leaf and stem weight. Talukder (1983) reported that during the beginning of the plant growth and development, leaves constituted more than $40 \%$ of the plant total dry weight. As plant development progressed, leaf contribution to the dry matter decreased very rapidly and stem contribution to the total dry matter increased sharply attaining a maximum of about 67 percent at the flowering stage, 
Table 4. Effect of deficit irrigation on dry matter accumulation during the study years.

\begin{tabular}{c|lll|l|l}
\hline \multirow{2}{*}{ Treatment } & \multicolumn{5}{c}{ DM (t/ha) } \\
\cline { 2 - 6 } & \multicolumn{1}{|c}{ CRI } & Vegetative & $\begin{array}{c}\text { Booting- } \\
\text { head. }\end{array}$ & Anthesis & \multicolumn{1}{c}{ GF } \\
\hline $\mathrm{T}_{1}$ & $0.279 \mathrm{~cd}$ & $1.146 \mathrm{ef}$ & $3.013 \mathrm{~g}$ & $6.335 \mathrm{efg}$ & $6.912 \mathrm{f}$ \\
$\mathrm{T}_{2}$ & $0.307 \mathrm{ab}$ & $1.285 \mathrm{de}$ & $4.453 \mathrm{~d}$ & $7.148 \mathrm{cde}$ & $8.706 \mathrm{cde}$ \\
$\mathrm{T}_{3}$ & $0.311 \mathrm{ab}$ & $1.423 \mathrm{~cd}$ & $4.495 \mathrm{~cd}$ & $8.008 \mathrm{abc}$ & $9.692 \mathrm{bc}$ \\
$\mathrm{T}_{4}$ & $0.312 \mathrm{ab}$ & $1.641 \mathrm{c}$ & $5.549 \mathrm{a}$ & $8.401 \mathrm{ab}$ & $10.590 \mathrm{ab}$ \\
$\mathrm{T}_{5}$ & $0.320 \mathrm{a}$ & $2.355 \mathrm{a}$ & $5.109 \mathrm{ab}$ & $8.450 \mathrm{a}$ & $11.300 \mathrm{a}$ \\
$\mathrm{T}_{6}$ & $0.282 \mathrm{~cd}$ & $0.935 \mathrm{f}$ & $3.747 \mathrm{f}$ & $6.086 \mathrm{fg}$ & $7.276 \mathrm{ef}$ \\
$\mathrm{T}_{7}$ & $0.264 \mathrm{~d}$ & $1.229 \mathrm{de}$ & $4.530 \mathrm{~cd}$ & $7.752 \mathrm{a}-\mathrm{d}$ & $8.090 \mathrm{def}$ \\
$\mathrm{T}_{8}$ & $0.297 \mathrm{bc}$ & $1.146 \mathrm{ef}$ & $4.188 \mathrm{de}$ & $6.911 \mathrm{def}$ & $8.585 \mathrm{cde}$ \\
$\mathrm{T}_{9}$ & $0.307 \mathrm{ab}$ & $1.977 \mathrm{~b}$ & $4.908 \mathrm{bc}$ & $7.497 \mathrm{bcd}$ & $9.410 \mathrm{bcd}$ \\
$\mathrm{T}_{10}$ & $0.310 \mathrm{ab}$ & $0.954 \mathrm{f}$ & $3.840 \mathrm{ef}$ & 5.708 & $7.797 \mathrm{ef}$ \\
\hline CV (\%) & 3.83 & 9.25 & 5.86 & 7.31 & 9.77 \\
LSD (5\%) & 0.020 & 0.224 & 0.441 & 0.906 & 1.482 \\
\hline
\end{tabular}

Total dry matter increased gradually until booting stage and then sharply increased until flowering stage. However, the rate of accumulation in no stress treatment is much higher than those of stressed treatments. The dry matter accumulation reached to its maximum at the grain formation stage.

It is to mention here that the treatment $T_{6}$ was irrigated at all major stages (four in total) except CRI whereas $\mathrm{T}_{1}$ (rainfed) was not irrigated at any stage. But the trend of dry, matter accumulation did not differ very much indicating that irrigation after CRI stage does not have very much impact on dry matter accumulation. Campbell and Davidson (1979) reported that high moisture stress from last leaf visible to anthesis markedly reduced dry matter accumulation in wheat. Waldren and Flowerdey (1979) found that dry matter accumulation increased rapidly from jointing to soft dough stage of wheat and translocation of dry matter from leaves to grain began at flowering stage. Gazri and Prihar (1983) reported that early season (30 days from seedling) water stress decreased the rate of dry matter accumulation.

\section{Effect of water deficit on yield contributing parameters}

The impact of water deficit on some other important yield contributing parameters revealed by the field experiments during the study years are 
summarized in Table 5. All important yield contributing parameters showed significant differences among the treatments. Moisture deficit (partially or fully) throughout the seasons reduced almost all yield contributing characters significantly. Many of the important yield contributing parameters in treatment $T_{4}$ was almost similar to no stress treatment $\left(T_{5}\right)$, because irrigation in $T_{4}$ was withheld at the grain formation stage that did not affect significantly on the overall growth and grain formation process. The highest plant height was observed in no stress treatment $\left(T_{5}\right)$ which was followed by the treatment not irrigated at the grain formation stage $\left(\mathrm{T}_{4}\right)$.

Table 5. Effect of deficit irrigation on various yield contributing parameters of wheat during thee study years.

\begin{tabular}{c|l|c|c|c|c}
\hline Treatments & $\begin{array}{c}\text { Plant } \\
\text { population/ } \\
\mathrm{m}^{2}\end{array}$ & Spikes/m² & $\begin{array}{c}\text { Spike length } \\
(\mathrm{cm})\end{array}$ & $\begin{array}{c}\text { Seeds/ } \\
\text { spike }\end{array}$ & $\begin{array}{c}1000 \text {-grain wt } \\
\text { (g) }\end{array}$ \\
\hline $\mathrm{T}_{1}$ & $283.0 \mathrm{cde}$ & $196.3 \mathrm{c}$ & $7.64 \mathrm{e}$ & $32.4 \mathrm{~d}$ & $37.66 \mathrm{~b}$ \\
$\mathrm{~T}_{2}$ & $284.4 \mathrm{~b}-\mathrm{e}$ & $240.0 \mathrm{~b}$ & $8.95 \mathrm{ab}$ & $38.4 \mathrm{abc}$ & $38.17 \mathrm{ab}$ \\
$\mathrm{T}_{3}$ & $293.4 \mathrm{ab}$ & $288.1 \mathrm{a}$ & $8.74 \mathrm{a}-\mathrm{d}$ & $38.9 \mathrm{abc}$ & $38.24 \mathrm{ab}$ \\
$\mathrm{T}_{4}$ & $278.7 \mathrm{de}$ & $296.9 \mathrm{a}$ & $8.74 \mathrm{a}-\mathrm{d}$ & $39.9 \mathrm{ab}$ & $39.32 \mathrm{ab}$ \\
$\mathrm{T}_{5}$ & $290.0 \mathrm{abc}$ & $306.0 \mathrm{a}$ & $9.08 \mathrm{a}$ & $40.7 \mathrm{a}$ & $37.46 \mathrm{~b}$ \\
$\mathrm{~T}_{6}$ & $276.0 \mathrm{e}$ & $281.3 \mathrm{a}$ & $9.05 \mathrm{ab}$ & $39.7 \mathrm{ab}$ & $37.21 \mathrm{~b}$ \\
$\mathrm{~T}_{7}$ & $283.0 \mathrm{cde}$ & $293.3 \mathrm{a}$ & $8.52 \mathrm{~cd}$ & $36.1 \mathrm{c}$ & $38.34 \mathrm{ab}$ \\
$\mathrm{T}_{8}$ & $286.0 \mathrm{bcd}$ & $288.6 \mathrm{a}$ & $8.92 \mathrm{abc}$ & $40.2 \mathrm{a}$ & $38.13 \mathrm{ab}$ \\
$\mathrm{T}_{9}$ & $298.6 \mathrm{a}$ & $285.9 \mathrm{a}$ & $8.65 \mathrm{bcd}$ & $39.1 \mathrm{ab}$ & $38.05 \mathrm{ab}$ \\
$\mathrm{T}_{10}$ & $283.7 \mathrm{cde}$ & $248.6 \mathrm{~b}$ & $8.38 \mathrm{~d}$ & $37.2 \mathrm{bc}$ & $40.75 \mathrm{a}$ \\
\hline CV (\%) & 9.34 & 5.72 & 2.87 & 4.49 & 2.869 \\
LSD (5\%) & 1.97 & 25.82 & 0.412 & 2.85 & 4.52 \\
\hline
\end{tabular}

The results on plant height, leaf area development, grain yield, straw yield, and dry matter accumulation during the three study years are presented in Table 6. Moisture deficit reduced significantly the mean grain weight as compared to no stress treatment $\left(T_{5}\right)$, particularly when stress occurred from emergence to vegetative stage (treatment $T_{1}, T_{10}$, etc.). Significant differences among the treatments in respect of plant height were observed. Obviously it was the minimum in case of the rainfed treatment. 
Table 6. Effect of water stress on growth parameters and yield during 2003-04 to 2005-2006.

\begin{tabular}{c|c|c|c|c|c|c}
\hline Treatment & $\begin{array}{c}\text { Plant } \\
\text { height } \\
(\mathrm{cm})\end{array}$ & Max. LAI & $\begin{array}{c}\text { Max. DM } \\
\text { t/ha }\end{array}$ & $\begin{array}{c}\text { Grain yield } \\
\text { t/ha }\end{array}$ & $\begin{array}{c}\text { Straw } \\
\text { yield } \\
\text { (t/ha) }\end{array}$ & $\begin{array}{c}\text { Av. } \\
\text { HI }\end{array}$ \\
\hline $\mathrm{T}_{1}$ & $89.45 \mathrm{c}$ & $2.40 \mathrm{~d}$ & $6.912 \mathrm{f}$ & $1.824 \mathrm{e}$ & $3.336 \mathrm{~d}$ & 0.35 \\
$\mathrm{~T}_{2}$ & $99.05 \mathrm{a}$ & $2.68 \mathrm{bcd}$ & $8.706 \mathrm{cde}$ & $3.372 \mathrm{c}$ & $4.577 \mathrm{c}$ & 0.38 \\
$\mathrm{~T}_{3}$ & $98.88 \mathrm{a}$ & $2.77 \mathrm{bc}$ & $9.692 \mathrm{bc}$ & $3.687 \mathrm{~b}$ & $5.090 \mathrm{~b}$ & 0.39 \\
$\mathrm{~T}_{4}$ & $101.30 \mathrm{a}$ & $3.48 \mathrm{a}$ & $10.590 \mathrm{ab}$ & $4.174 \mathrm{a}$ & $5.805 \mathrm{a}$ & 0.39 \\
$\mathrm{~T}_{5}$ & $101.60 \mathrm{a}$ & $3.12 \mathrm{~b}$ & $11.300 \mathrm{a}$ & $4.235 \mathrm{a}$ & $5.815 \mathrm{a}$ & 0.39 \\
$\mathrm{~T}_{6}$ & $98.56 \mathrm{a}$ & $1.97 \mathrm{e}$ & $7.276 \mathrm{ef}$ & $3.383 \mathrm{c}$ & $4.828 \mathrm{bc}$ & 0.39 \\
$\mathrm{~T}_{7}$ & $98.35 \mathrm{ab}$ & $2.52 \mathrm{~cd}$ & $8.090 \mathrm{def}$ & $3.617 \mathrm{bc}$ & $5.616 \mathrm{a}$ & 0.37 \\
$\mathrm{~T}_{8}$ & $99.18 \mathrm{a}$ & $2.48 \mathrm{~cd}$ & $8.585 \mathrm{cde}$ & $3.447 \mathrm{bc}$ & $4.644 \mathrm{bc}$ & 0.40 \\
$\mathrm{~T}_{9}$ & $98.50 \mathrm{ab}$ & $2.91 \mathrm{~b}$ & $9.410 \mathrm{bcd}$ & $3.603 \mathrm{bc}$ & $5.359 \mathrm{ab}$ & 0.39 \\
$\mathrm{~T}_{10}$ & $94.71 \mathrm{~b}$ & $2.00 \mathrm{e}$ & $7.797 \mathrm{ef}$ & $3.066 \mathrm{~d}$ & $4.558 \mathrm{c}$ & 0.37 \\
\hline $\mathrm{CV}(\%)$ & 3.813 & 7.09 & 9.77 & 4.69 & 5.96 & \\
LSD (5\%) & 2.27 & 0.316 & 1.482 & 0.267 & 0.494 & \\
\hline
\end{tabular}

Like plant height, highest LAI value was also observed in no stress treatment $\mathrm{T}_{5}$ which was followed by $\mathrm{T}_{4}$ (Table 6). But it is important to note here that LAI growth was exceptionally lower in case of treatments $T_{6}, T_{8}$, and $T_{10}$. Moisture stress was imposed in case of all these treatments at CRI stage. Treatment $T_{2}$ was irrigated only once (at CRI stage) and $\mathrm{T}_{3}$ was irrigated twice (at CRI and anthesis stages). Beside this, treatment $\mathrm{T}_{6}$ was irrigated four times except CRI stage. But the LAI development for $T_{2}$ and $T_{3}$ were much more than that of $T_{6}$. The results indicate that irrigation at CRI stage is much more effective than a regular irrigation afterwards in respect of LAI development.

Table 6 shows that the maximum DM for all the treatments was attained around at the grain filling stage. Almost a similar trend of growth as observed in case of LAI development was also found in case of DM accumulation. A small percentage of DM was decreased at harvest due to senescence at maturity stage.

In general, total biomass accumulation increased with the increase of water use. An exception was observed in case of the treatments in which water stress was imposed at CRI stage (e. g., treatment $\mathrm{T}_{6}$ ). Four irrigations were applied in total to both the treatments $\mathrm{T}_{4}$ and $\mathrm{T}_{6}$. But higher dry matter (10593 kg/ha) was accumulated in $\mathrm{T}_{4}$ than in $\mathrm{T}_{6}(7276 \mathrm{~kg} / \mathrm{ha})$. This result indicates that, stress at CRI stage is much more harmful than that at grain formation stage. It was also observed that irrigation at vegetative stage is also very important for dry matter accumulation as observed in treatments, $\mathrm{T}_{7}$ and $\mathrm{T}_{9}$ ). 


\section{Effect of water deficit on yield, water use, and water productivity}

Table 7 shows the three years' results on irrigation applied, water use (consumptive use) yield, and water productivity (WP). Different combinations of irrigation number and timing produced different yields. The treatment $T_{5}$ with 5 irrigations produced the highest yield but it was very close to the treatment $\left(\mathrm{T}_{4}\right)$, irrigated four times.

Table 7. Irrigation applied, water use and water productivity (WP) of wheat during the study years.

\begin{tabular}{c|c|c|c|c|c}
\hline Treatment & $\begin{array}{c}\text { No. of } \\
\text { irrigations }\end{array}$ & $\begin{array}{c}\text { Amount of } \\
\text { irrig. }(\mathrm{mm})\end{array}$ & $\begin{array}{c}\mathrm{CU} \\
(\mathrm{mm})\end{array}$ & $\begin{array}{c}\text { Yield } \\
(\mathrm{t} / \mathrm{ha})\end{array}$ & $\begin{array}{c}\mathrm{WP} \\
\left(\mathrm{kg} / \mathrm{m}^{3}\right)\end{array}$ \\
\hline $\mathrm{T}_{1}$ & 0 & $0 \mathrm{f}$ & $140 \mathrm{f}$ & $1.824 \mathrm{e}$ & 1.30 \\
$\mathrm{~T}_{2}$ & 1 & $61 \mathrm{e}$ & $186 \mathrm{e}$ & $3.372 \mathrm{c}$ & 1.81 \\
$\mathrm{~T}_{3}$ & 2 & $114 \mathrm{~d}$ & $237 \mathrm{~d}$ & $3.687 \mathrm{~b}$ & 1.56 \\
$\mathrm{~T}_{4}$ & 4 & $212 \mathrm{~b}$ & $309 \mathrm{~b}$ & $4.174 \mathrm{a}$ & 1.37 \\
$\mathrm{~T}_{5}$ & 5 & $262 \mathrm{a}$ & $331 \mathrm{a}$ & $4.235 \mathrm{a}$ & 1.28 \\
$\mathrm{~T}_{6}$ & 4 & $220 \mathrm{~b}$ & $294 \mathrm{bc}$ & $3.383 \mathrm{c}$ & 1.15 \\
$\mathrm{~T}_{7}$ & 3 & $166 \mathrm{c}$ & $283 \mathrm{c}$ & $3.617 \mathrm{bc}$ & 1.28 \\
$\mathrm{~T}_{8}$ & 3 & $170 \mathrm{c}$ & $286 \mathrm{bc}$ & $3.447 \mathrm{bc}$ & 1.21 \\
$\mathrm{~T}_{9}$ & 2 & $111 \mathrm{~d}$ & $255 \mathrm{~d}$ & $3.603 \mathrm{bc}$ & 1.41 \\
$\mathrm{~T}_{10}$ & 2 & $109 \mathrm{~d}$ & $232 \mathrm{~d}$ & $3.066 \mathrm{~d}$ & 1.32 \\
\hline $\mathrm{CV}(\%)$ & - & 3.63 & 5.87 & 4.69 & - \\
LSD (5\%) & - & 8.58 & 24.8 & 0.267 & - \\
\hline
\end{tabular}

The other studies have reported that the relationship between yield and water consumption including irrigation is non-linear (Yuan et al., 1992). The results of the present study showed the crop yields initially improved with increased water consumption, but beyond a certain water use level yields were not increased similarly. Although four irrigations were applied in treatment $\mathrm{T}_{4}$, its yield (4.174 $\mathrm{t} / \mathrm{ha}$ ) is very close to that of treatment $T_{5}(4.235 \mathrm{t} / \mathrm{ha})$ which was irrigated five times. This indicates that one more irrigation at grain formation stage is insignificant in respect of grain yield. In general, differences in grain and straw yields among the irrigated treatments were small, but there was a sharp contrast between irrigated and full deficit treatment. In case of normal climatic condition, the pattern of response to irrigation was almost similar. The vital effect of irrigation on yield was observed with the addition of first application of water at CRI stage (treatment $\mathrm{T}_{2}$ ).

Deficit irrigation affects crop growth and reduce their grain yield (GY), whereas the effects are different under different irrigation schedules. Treatment $\mathrm{T}_{1}$ represents a severe soil water deficit condition. Mean GY and biomass of 
treatment $T_{1}$ were evidently lower than those of the other treatments and the 3 years' average GY of treatment $\mathrm{T}_{1}$ was only $44.79 \%$ of treatment $\mathrm{T}_{5}$ which showed that severe soil water deficit markedly decreased GY and its biomass, compared to those of other treatments.

\section{Gain yield (GY)-consumptive use (CU) relationships}

The average trend of increase of yield with increase of water use is graphically shown in Figure 1. The relationship shows that initially the crop yield increased with increased consumptive use at a higher rate but later on, it was increased at a lower rate. The grain yield-consumptive use relationship can be denoted by the following quadratic function.

$$
y=-0.0385 x^{2}+27.311 x-964.42
$$

where: $y=$ grain yield $(\mathrm{GY}), \mathrm{kg} / \mathrm{ha}$ and

$\mathrm{x}=$ consumptive use $\mathrm{CU}), \mathrm{mm}$

From the GY-CU relationship, the consumptive use for optimum grain yield was predicted as $355 \mathrm{~mm}$.

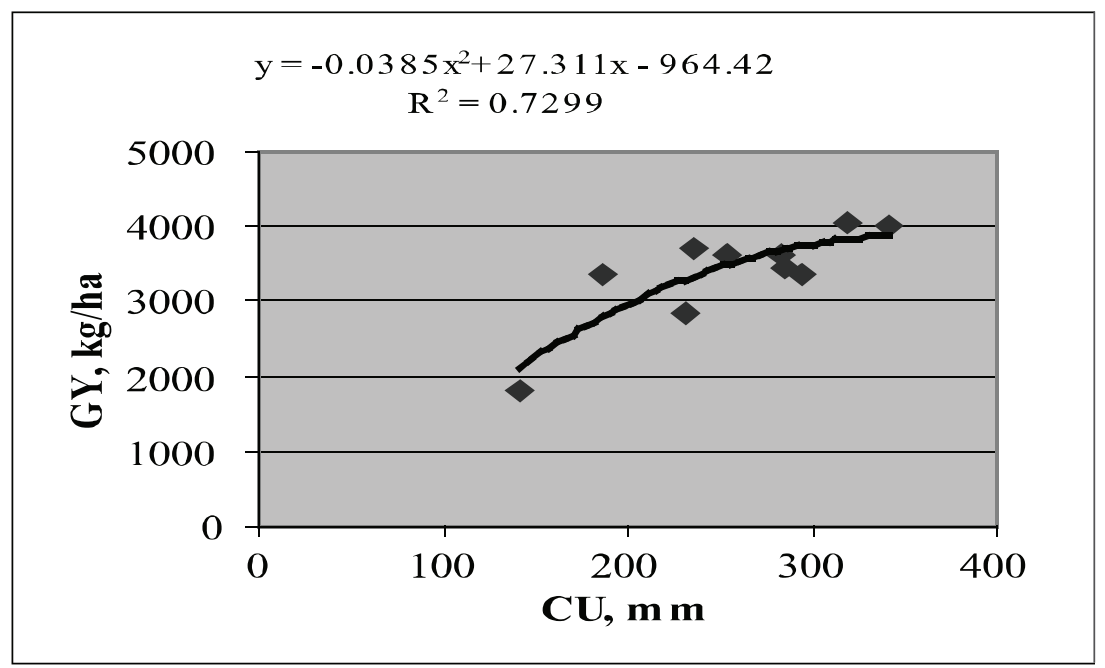

Fig. 1. Relationship of grain yield (GY) with consumptive use (CU).

\section{Conclusion}

Water demand for proper growth of wheat is not similar at different growth stages. Some stages are very sensitive to water stress, whereas the crop easily can tolerate a slight soil water deficit during some other stages. Comparatively CRI (17-21 days after sowing) stage is much more sensitive to soil moisture stress than the following growth stages throughout the cropping season. If only one 
irrigation up to the field capacity is applied at that stage, as much as $80 \%$ of the optimum yield can be obtained. A negligible yield reduction (less than 2\%) occurs if soil water stress is imposed at the grain formation stage subjected to irrigation applied at the previous important growth stages. So it is recommended that at least one irrigation at CRI stage should be applied to avoid drastic yield reduction in case of water scarcity. To attain an optimum yield, wheat should be irrigated at CRI, vegetative, booting, and flowering stages. Soil moisture deficit at the grain formation stage does not do a reasonable harm in respect of yield.

\section{References}

Ali, M. H., M. R. Haque, and M. A. Khair. 2008. Effective management of water in wheat cultivation under water limiting condition. Proceedings of Paper Meet, Agril. Engg. Division, The Institute of Engineers, Bangladesh. Pp. 15-26.

Campbell, C. A. and H. R. Davidson. 1979. Effect of temperature, nitrogen fertilization and moisture stress on yield, yield components, protein content and moisture use efficiency of Manitou spring wheat. Canadian J. of Plant Sci. 59: 963-974.

Fertilizer Recommendations Guide - 2005. Bangladesh Agricultural Research Council. Farm Gate, New Airport Road, Dhaka - 1215.

Gazri, P. R. and S. S. Prihar. 1983. Effect of small irrigation amounts on the yield of wheat. Agric. Wat. Mgt. 6: 31-41.

Kirda, C. and R. Kanber. 1999. Water is no longer a plentiful resource, should be used sparingly in irrigated agriculture. In: Kirda, C., P. Mouttonnet, and D. R. Nielsen, (eds). Crop yield response to deficit irrigation. Dordrecht, The Netherlands, Kluwer, Academic Publishers.

Kramer, P. J. 1959. The role of water in the physiology of plants. Adv. Agron. 11: 51-70.

Manalo, E. B. 1976. Agroclimatic survey of Bangladesh. International Rice Research Institute (IRRI), Philippines. 387 P.

Pereira, L. S., T. Owesis and A. Zairi. 2002. Irrigation management under water scarcity. Agric. Wat. Mgt. 57: 175-206

Rodrigues, P. N., L. S. Pereira, A. Zairi, H. El Amami, H. A. Slatni, J. L. Teixeira, and T. Machado. 2001. Deficit Irrigation of Cereals and Horticultural Crops: Simulation of Strategies to Cope with Droughts. Agricultural Engineering International: the CIGR Journal of Scientific Research and Development. Manuscript I. W. 00007a. Vol. III.

Talukder, M. S. U. 1983. Growth, yield, and water relations of wheat subjected to soil moisture stress. Ph.D dissertation, Royal Veterinary and Agricultural University, Copenhagen, Denmark. 214 P.

Vaadia, Y., F. C. Raney and R. M. Hazan.1961. Annu. Rev. PlantPhysiol. 12: 265-292.

Waldren, R. P. and A. D. Flowerday. 1979. Growth stages and distribution of dry matter, N, P, and K in winter wheat. Agron. J. 71: 391-397. 
Yuan, X., H. Wang, X. Zhang and M. You. 1992. The relationship between winter wheat, yield and water consumption. In: Researches on the Relationship of Crop with Water. Sci. and Tech. Beijing, Publishing House (in Chinese).

Zhang, Y., E. Kendy, Y. Qiang, L. Changming, S. Yianjun and S. Hongyong. 2004. Effect of soil water deficit on evepotranspiration, crop yield and water use efficiency in North China Plain. Agric. Water Management 64: 107-122. 